UNIVERSITAS AHMAD DAHLAN
JURNAL BIOEDUKATIKA
2 http://journal.uad.ac.id/index.php/BIOEDUKATIKA
$2338-6630$ (Print)

\title{
Validitas buku ilmiah populer tentang echinodermata di Pulau Sembilan kotabaru untuk siswa SMA di kawasan pesisir
}

\author{
M. Fitriansyah ${ }^{a, 1 *}$, Yudi Firmanul Arifina, ${ }^{a}$, Danang Biyatmokoa, 3 \\ a Program Studi Magister Pendidikan Biologi Fakultas Keguruan dan Ilmu Pendidikan Universitas Lambung Mangkurat, Jl. Brigjen H. \\ Hasan Basri, Banjarmasin, Indonesia. \\ ${ }^{1}$ Muhammadfitriansyah03@gmail.com*; ${ }^{2}$ Yudifirmanul@unlam.ac.id; ${ }^{3}$ Danangbiyatmoko@ulm.ac.id \\ *korespondensi penulis
}

\begin{tabular}{ll}
\hline Informasi artikel & \\
\hline Sejarah artikel: & \\
Diterima & 28 Maret 2018 \\
Revisi & 20 Juni 2018 \\
Dipublikasikan & 30 Juni 2018 \\
\hline
\end{tabular}

Kata kunci:
Validitas
Buku Ilmiah populer
Echinodermata
Penelitian pengembangan.
\begin{abstract}
ABSTRAK
Pembelajaran dengan menggunakan buku ilmiah populer berdasarkan potensi lokal yang dimiliki sebuah daerah merupakan salah satu solusi yang dapat digunakan untuk mengatasi permasalahan-permasalahan yang sering muncul dalam pembelajaran materi invertebrata khususnya echinodermata yang memiliki materi cukup banyak dan kompleks. Penelitian pengembangan ini bertujuan untuk mendeskripsikan validitas prototipe buku ilmiah populer yang berjudul "Hewan Berduri dari Pesisir Pulau Denawan”. Metode penelitian yang digunakan ialah model pengembangan oleh Plomp dan Nieveen yang dibatasi sampai pada fase evaluasi formatif berdasarkan model Tessmer. Hasil penelitian menunjukkan bahwa buku ilmiah populer yang telah dikembangkan memperoleh kriteria sangat valid berdasarkan hasil validasi ahli dengan rata-rata persentase sebesar $88,02 \%$ dan guru mitra dengan persentase sebesar 90,1\%, sedangkan berdasarkan uji perorangan buku ilmiah populer ini mendapatkan kriteria sangat baik dengan persentase rata-rata sebesar 90,1\%. Hasil tersebut menggambarkan bahwa buku ilmiah populer yang telah dikembangkan memiliki tingkat validitas yang sangat tinggi karena telah bersifat kontekstual, memiliki bahasa yang mudah dipahami, memiliki tampilan yang menarik, sesuai dengan pembelajaran saintifik, dan dapat mengembangkan kemampuan berpikir kritis. Buku ilmiah populer "Hewan Berduri dari Pesisir Pulau Denawan” dapat menjadi media pembelajaran untuk meningkatkan kualitas pembelajaran dan hasil belajar siswa pada materi echinodermata.
\end{abstract}

Key word:

Validity

Popular scientific books

Echinoderms

Research development

\begin{abstract}
Learning by using popular scientific books based on local potential owned by a region is one solution that can be used to overcome the problems that often arise in the learning of invertebrate materials, especially echinoderms that have enough material and complex. This development research aims to describe the validity of the prototype of a popular scientific book entitled "Hewan Berduri dari Pesisir Pulau Denawan”. The research method used is a development model by Plomp and Nieveen which is limited to formative evaluation phase based on Tessmer model. The results showed that the popular scientific books that have been developed to obtain criteria very valid based on the validation of experts with average percentage of $88.02 \%$ and partner teachers with a percentage of $90.1 \%$, while based on the individual test of this popular scientific book get very criteria both with an average percentage of $90.1 \%$. These results illustrate that popular scientific books that have been developed have a very high degree of validity because they are contextual, have a language that is easy to understand, has an attractive appearance, in accordance with scientific learning, and can develop critical thinking skills. The popular scientific book "Hewan Berduri dari Pesisir Pulau Denawan" can be a medium of learning to improve the quality of learning and student learning outcomes on echinodermata material.
\end{abstract}

Copyright (C) 2018 Universitas Ahmad Dahlan 


\section{Pendahuluan}

Kualitas pendidikan di Indonesia dari masa ke masa selalu berubah untuk menyesuaikan perkembangan zaman dan teknologi, akan tetapi seiring berjalannya waktu banyak masalah yang muncul. Salah satu masalah yang sering muncul adalah rendahnya daya serap siswa terhadap materi pembelajaran. Hal ini terlihat dari rerata hasil belajar siswa yang menunjukkan hasil dibawah rata-rata. Hasil ini merupakan akibat dari kondisi pembelajaran yang masih bersifat konvensional dan tidak menyentuh ranah dimensi siswa itu sendiri, yaitu bagaimana sebenarnya belajar itu. Dalam artian yang lebih substansional, proses pembelajaran hingga dewasa ini masih memberikan dominansi guru dan tidak memberikan akses bagi siswa untuk berkembang secara mandiri melalui penemuan dan proses berfikirnya (Trianto, 2008).

Kurikulum yang dikembangkan hendaknya menyesuaikan dengan potensi yang dimiliki masing-masing daerah, hal tersebut tentu dapat memberdayakan siswa sesuai dengan potensi dan kebutuhan diri dan lingkungannya, sehingga terbuka peluang yang sangat besar bagi daerah dan pengelola pendidikan untuk melakukan adaptasi, modifikasi, dan kontekstualisasi kurikulum sesuai dengan potensi yang dimiliki daerahnya dan kenyataan yang ada di lapangan seperti (1) ekologis, (2) demografis, (3) geografis, (4) sosiologis, (5) kultural, dan (6) psikologis siswa (Suja, 2010). Hal tersebut didukung oleh Aunurrahman (2014) yang menyatakan bahwa pihak-pihak yang berkaitan dengan pendidikan seharusnya dapat mengoptimalkan pemanfaatan potensi lokal yang dimiliki daerahnya sebagai bahan pembelajaran. Hal ini dapat diwujudkan melalui pendidikan yang berorientasi pada potensi lokal dengan tetap diarahkan untuk meningkatkan kemampuan dan prestasi siswa, karena proses pendidikan tidak hanya dilakukan dengan cara mentrasfer ilmu dari guru ke siswa, akan tetapi siswa harus mampu belajar dari lingkungan dan kehidupan sehari-hari.

Salah satu upaya perbaikan untuk memperbaiki pendidikan di Indonesia berdasarkan amanah dari kurikulum 2013 ialah dengan melakukan pengembangan buku ajar yang tujuannya ialah untuk melakukan pembaharuan dan penyediaan terhadap buku ajar. Hal tersebut sesuai dengan Mahmud (2013) yang menjelaskan bahwa tersedianya buku merupakan salah satu faktor yang dapat memperbaiki pendidikan khususnya di Indonesia.

Buku yang baik hendaknya dikembangkan dan dibuat berdasarkan potensi-potensi lokal yang dimiliki sebuah daerah, sehingga pembelajaran akan berjalan lebih efektif dan efisien, hal terebut dikarenakan siswa sering berinteraksi secara langsung dengan lingkungan mereka. Akan tetapi masih belum banyak buku-buku yang dikembangkan dan diimplementasikan pada siswa yang sumbernya berasal dari potensi lokal. Hal tersebut sejalan dengan Dharmono, Syahdi, \& Muchyar (2017) yang menjelaskan bahwa bahan ajar dapat berasal dari potensi lokal yang dimiliki oleh sebuah daerah, sehingga dengan adanya penelitian ini diharapkan timbul penelitianpenelitian lain untuk mengembangkan buku berbasis potensi lokal, mengingat pentingnya hal ini terus dilakukan untuk menggali potensi-potensi yang ada.

Penggunaan buku sebagai bahan ajar dapat dilakukan untuk menerapkan pembelajaran secara individual, hal tersebut dikarenakan buku biasanya dikemas dengan materi yang lengkap dan diimplementasikan dengan tahapan yang runtut dalam sebuah proses pembelajaran. Hal tersebut sesuai dengan Lestari (2012) yang menyatakan bahwa buku atau bahan ajar adalah alat pembelajaran yang berisi materi pembelajaran, metode, batasan-batasan, dan cara mengevaluasi yang didesain secara sistematis dan menarik, hal tersebut dilakukan untuk mencapai tujuan yang diharapkan seperti kompetensi, subkompetensi, dan segala kompleksitasnya, sehingga dapat digunakan untuk pembelajaran secara mandiri atau individual.

Buku ilmiah populer merupakan salah satu karya tulis yang pembuatannya berdasarkan kaidah-kaidah metode ilmiah, namun dijabarkan dengan kalimat yang sederhana dan ditampilkan secara menarik sehingga memudahkan pembaca untuk memahami sebuah karya ilmiah yang biasanya dianggap susah dipahami oleh masyarakat awam. Menurut Setiawan (2017) buku ilmiah populer merupakan salah satu jenis buku yang berisi ilmu pengetahuan dan menyajikan fakta serta ditulis dengan bahasa yang mudah dan menarik. Buku ini diharapkan dapat membantu siswa dan masyarakat untuk membangun pengetahuannya tentang echinodermata di Kecamatan Pulau Sembilan.

Buku ilmiah populer sendiri pada hakikatnya dapat dimanfaatkan oleh semua kalangan, baik oleh siswa dari berbagai jenjang dan tingkatan pendidikan serta masyarakat umum (Pammai, 2014). Hasil wawancara dari petugas Kecamatan Pulau Sembilan, diketahui bahwa masih belum ada buku ilmiah populer yang membahas tentang echinodermata di Kecamatan Pulau Sembilan khususnya jenis-jenis echinodermata yang ditemukan di Pulau Denawan. Hal tersebut melatarbelakangi penulis untuk mengembangkan buku ilmiah populer tentang echinodermata di Kecamatan Pulau Sembilan.

Di Kecamatan Pulau Sembilan sangat melimpah sumber daya alam berupa hewan-hewan laut, hal tersebut dikarenakan wilayah ini sebagian besar masih bersih dari pencemaran sehingga sumberdaya alamnya masih terjaga. Salah satu hewan pesisir pantai yang masih banyak terdapat di wilayah ini ialah hewan-hewan dari filum echinodermata.

Echinodermata merupakan salah satu Filum dari kelompok hewan invertebrata atau hewan yang tidak bertulang belakang. Menurut Nontji (2007) echinodermata ialah hewan-hewan laut yang kulitnya berbintil atau berduri. Hewan-hewan ini sangat umum dijumpai di daerah pantai terutama di daerah terumbu karang. Di Indonesia terdapat kurang lebih 141 jenis teripang, 87 jenis bintang laut, 142 jenis bintang ular, 84 jenis bulu babi, dan 91 jenis lili laut.

Penelitian tentang pengembangan buku ilmiah populer dari hasil penelitian sudah dilakukan oleh beberapa orang, seperti penelitian oleh Setiawan (2017) yang melakukan pengembangan buku ilmiah populer untuk masyarakat pecinta alam melalui eksplorasi tumbuhan survival di Taman Nasional Bromo Tengger Semeru yang hasilnya ialah buku tersebut memiliki materi yang sangat 
baik dan sudah valid digunakan menyampaikan informasi tentang tumbuhan survival. Pammai (2014) yang melakukan studi keanekaragaman anggrek di Kabupaten Merauke untuk pengembangan buku ilmiah populer sebagai upaya pelestarian sumber daya lokal bagi masyarakat Merauke, dimana hasilnya ialah buku ilmiah populer tersebut telah memiliki validitas yang tinggi sehingga dapat digunakan sebagai sumber informasi bagi masyarakat khususnya masyarakat kabupaten Merauke. Selanjutnya penelitian yang dilakukan oleh Zakyah (2016) yang melakukan pengembangan buku ilmiah populer tentang struktur pasir terhadap tingkat keberhasilan penetasan telur penyu hijau di taman Nasional Meru Betiri yang mana hasilnya menyatakan bahwa buku ilmiah populer tersebut valid digunakan sebagai bahan bacaan. Dari ketiga penelitian diatas dapat disimpulkan bahwa buku ilmiah populer yang telah dikembangkan oleh beberapa peneliti diatas memiliki validitas yang tinggi sebagai bahan bacaan baik untuk siswa maupun masyarakat agar menambah wawasan yang mereka miliki. Penelitian pengembangan buku ilmiah populer tentang echinodermata ini diharapkan juga mendapat validitas yang tinggi sehingga dapat digunakan sebagai bahan belajar ataupun bahan bacaan.

Perlunya sumber belajar yang dalam bentuk buku ilmiah populer tentang echinodermata yang berbasis potensi lokal untuk menarik minat siswa untuk belajar dan belum adanya penelitian tentang filum echinodermata untuk konsep invertebrata di Kecamatan Pulau Sembilan mendorong peneliti untuk mengembangkan buku ilmiah populer tentang echinodermata di Kecamatan Pulau Sembilan Kotabaru untuk siswa SMA di kawasan pesisir.

\section{Metode}

Penelitian pengemabangan ini merupakan penelitian yang mengacu pada tahap pengembangan dari Plomp \& Nieveen, (2007) yamg terdiri dari 3 tahap yaitu, (1) preliminary research, (2) prototyping phase, dan (3) assessment phase, akan tetapi, penelitian pengembangan ini hanya sampai pada langkah prototyping phase yang pada hakikatnya setara dengan evaluasi formatif.

Tahap preliminary research atau investigasi awal merupakan tahap yang digunakan untuk melakukan pengkajian terhadap analisis konteks, tinjauan literatur, pengembangan kerangka konseptual atau teoritis. Kegiatankegiatan yang dilaksanakan dalam tahap ini ialah melakukan pengumpulan informasi untuk mengkaji standar kompentensi kurikulum 13 dalam pembelajaran SMA kelas X khususnya yang ada di SMAN 1 Pulau Sembilan. Lalu dilakukan pengkajian terhadap masalah-masalah yang sering terjadi pada pembelajaran Invertebrata khususnya submateri echinodermata di SMAN 1 Pulau Sembilan. Langkah selanjutnya ialah menemukan solusi dari masalahmasalah tersebut berdasarkan potensi yang dimiliki oleh Kecamatan Pulau Sembilan pada umumnya dan oleh Pulau Denawan pada khususnya, dimana pada daerah ini sangat melimpah jenis-jenis echinodermata, namun banyak siswa ataupun masyarakat yang masih belum mengenal jenisjenisnya termasuk pemanfaatan dan pelestarianya.
Berdasarkan analisis masalah tersebut solusi terbaik yang dapat dilakukan ialah dengan mengembangkan buku ilmiah populer berdasarkan potensi yang dimiliki oleh Kecamatan Pulau Sembilan yaitu hewan echinodermata. Sebelum masuk dalam tahap pengembangan terlebih dahulu dilakukan penelitian pendahuluan yang bertujuan untuk mendapatkan data jenis-jenis echinodermata di Pulau Denawan. Setelah data tersebut didapat, maka langkah selanjutnya ialah membuat draf buku ilmiah populer yang berjudul "Hewan Berduri dari Pesisir Pulau Denawan".

Prototyping phase adalah sebuah tahap evaluasi formatif terhadap produk yang dalam penelitian ini berupa buku ilmiah populer. Model evaluasi formatif yang digunakan ialah model yang dikemukaan oleh Tessmer (1993) yang terdiri atas 5 langkah utama seperti evaluasi diri, uji pakar, uji perorangan, uji kelompok kecil, dan uji lapangan. Validitas prototipe buku ilmiah populer tentang echinodermata di Pulau Sembilan Kotabaru untuk siswa SMA di kawasan Pesisir ini diperoleh dari hasil uji pakar (ahli dan guru mitra) dan uji perorangan (siswa).

Prototipe buku ilmiah populer tentang echinodermata yang berjudul "Hewan Berduri dari Pesisir Pulau Denawan” ini divalidasi oleh 3 orang orang validator dari kalangan ahli yang merupakan dosen Magister Pendidikan Biologi FKIP ULM Banjarmasin dan 1 orang guru mitra yang merupakan guru biologi dari SMAN 1 Sembilan, Kotabaru. Sedangkan uji perorangan dilakukan oleh 3 siswa-siswi kelas XI SMAN 1 Pulau Sembilan yang dipilih langsung oleh pihak sekolah.

Validasi buku ilmiah populer dilakukan terhadap berbagai aspek seperti koherensi, keterbacaan, kosa kata (ungkapan, kerja, pilihan, yang berlebihan), kalimat aktif dan pasif, melindungi nilai (kata-kata yang bermakna ketidakpastian), aplikasi, implikasi, definisi dan penjelasan, dan gaya lain perangkat (narasi, humor, analogi). Data hasil validasi oleh validator terhadap buku ilmiah populer tentang echinodermata dianalisis melalui langkah-langkah berikut:

a. Menentukan skor validitas buku ilmiah populer dari ahli/pakar dan guru mitra dengan menggunakan mean.

b. Menghitung rata-rata semua hasil validasi oleh ahli/pakar dan guru mitra. Rata-rata ditentukan dengan menggunakan rumus 1 :

$$
X=\frac{\sum X}{n} \times 100 \% \text {........................ (Setyosari, 2013) }
$$

Berdasarkan rumus tersebut nilai rata-rata $(\mathrm{X})$ diperoleh dengan membagi jumlah skor seluruh validator $\left(\sum X\right)$ dengan jumlah validator (n) kemudian dikali 100\% sehingga diperoleh nilai rata-rata dalam bentuk persentase.

c. Hasil validitas yang diketahui persentasenya dikonversi dalam kriteria dengan menggunakan kriteria validitas sebagaimana tersaji pada tabel 1 .

Tabel I. Kriteria validitas

\begin{tabular}{ccl}
\hline Persentase & Kriteria & Keterangan \\
\hline $80,1-100 \%$ & Sangat valid & Tanpa revisi \\
$60,1-80 \%$ & Valid & Revisi kecil \\
$40,1-60 \%$ & Cukup valid & Revisi kecil \\
$20,1-40 \%$ & Kurang valid & Revisi besar \\
$0-20 \%$ & Tidak valid & Revisi total \\
\hline \multicolumn{2}{c}{ Dimodifikasi dari (Millah, Budipramana, \& Isnawati, 2012) }
\end{tabular}


Uji perorangan dilakukan terhadap aspek tampilan dan penyajian buku ilmiah populer. Data hasil uji perorangan terhadap buku ilmiah populer tersebut dianalisis menggunakan rumus sebagai berikut:

$$
P=\frac{X}{\sum X} \times 100 \%
$$

Keterangan: $\mathrm{P}$ adalah persentase, $\mathrm{X}$ adalah total skor yang diperoleh, dan $\sum X$ adalah jumlah seluruh skor.

Persentase keterbacaan siswa dikonversi sesuai dengan kriteria yang tersaji pada tabel 2:

Tabel 2. Kriteria uji perorangan

\begin{tabular}{cc}
\hline Persentase & Kriteria \\
\hline $80,1 \%-100 \%$ & Sangat baik \\
$60,1 \%-80 \%$ & baik \\
$40,1 \%-60 \%$ & Sedang \\
$20,1 \%-40 \%$ & Tidak baik \\
$0,0 \%-20 \%$ & Sangat tidak baik \\
\hline (Dimodifikasi dari Pasemawati, Fadiawati, \& Tania, 2013)
\end{tabular}

Tabel 3. Hasil validasi ahli terhadap buku ilmiah populer

\begin{tabular}{|c|c|c|}
\hline Aspek & Kriteria Penulisan Populer & Rata-rata Skor \\
\hline Aspek koherensi. & $\begin{array}{l}\text { Setiap paragraf memiliki satu ide pokok. } \\
\text { Antar kalimat menggunakan penghubung. } \\
\text { Ide-ide saling berurutan. } \\
\text { Kalimat telah mengarahkan kepada pemahaman. }\end{array}$ & 3,5 \\
\hline Aspek keterbacaan. & Teks sesuai dengan tingkat usia/tingkat pendidikan. & 3,7 \\
\hline $\begin{array}{l}\text { Aspek kosa kata: ungkapan, kerja, } \\
\text { pilihan, yang berlebihan. }\end{array}$ & $\begin{array}{l}\text { Penggunaan ungkapan dibatasi } \\
\text { Kosa kata yang digunakan sudah disesuaikan dengan tingkat } \\
\text { pembaca. }\end{array}$ & 3,3 \\
\hline Aspek kalimat aktif dan pasif. & Kalimat yang digunakan lebih jelas dan meyakinkan. & 3,3 \\
\hline $\begin{array}{l}\text { Aspek melindungi nilai: Kata-kata } \\
\text { yang bermakna ketidakpastian }\end{array}$ & Tidak menggunakan kata-kata yang bermakna ketidakpastian. & 3,7 \\
\hline Aspek aplikasi, implikasi. & $\begin{array}{l}\text { Penerapan: memasukkan isu-isu yang layak diberitakan dan } \\
\text { potensi aplikasi dunia nyata untuk kepentingan pembaca. }\end{array}$ & 3,7 \\
\hline Aspek definisi dan penjelasan. & $\begin{array}{l}\text { Penjelasan: Menjelaskan yang baik seperti mendeskripsikan, } \\
\text { memberikan contoh, analogi atau metafora untuk memfasilitasi } \\
\text { pemahaman pembaca }\end{array}$ & 3,7 \\
\hline $\begin{array}{l}\text { Aspek gaya lain perangkat: } \\
\text { narasi, humor, analogi. }\end{array}$ & $\begin{array}{l}\text { Penggunaan analogi untuk menjelaskan ide yang kompleks. } \\
\text { Penggunaan narasi untuk menjelaskan seperti dalam cerita fiksi } \\
\text { Penggunaan humor untuk kreativitas }\end{array}$ & 3,3 \\
\hline & $\begin{array}{c}\text { Total Skor } \\
\text { Persentase }(\%) \\
\text { Kriteria keseluruhan }\end{array}$ & $\begin{array}{c}28,2 \\
88,02 \\
\text { Sangat valid }\end{array}$ \\
\hline
\end{tabular}

BIP tentang echinodermata yang berjudul "Hewan Berduri dari Pesisir Pulau Denawan" memperoleh nilai persentase sebesar $89,3 \%$ dari validator pertama, $83,9 \%$ dari validator kedua, dan $87,5 \%$ dari validator ketiga. Selanjutnya nilai validasi terhadap BIP dari ketiga validator tersebut dikonversikan berdasarkan aspek-aspek yang ada pada lembar validasi dan mendapat nilai rata-rata sebesar $88,02 \%$, persentase tersebut masuk kedalam kriteria sangat valid atau dapat digunakan tanpa revisi.

Hasil diatas sejalan dengan Pammai (2014) yang melakukan pengembangan buku ilmiah populer tentang keanekaragaman anggrek di Merauke mendapatkan hasil dengan rata-rata $82,53 \%$ yang artinya buku ilmiah populer tersebut sangat layak digunakan sebagai sumber informasi tentang tumbuhan aggrek di Merauke Provinsi Papua. Akan tetapi hasil penelitian pengembangan ini lebih baik karena mendapatkan persentase rata-rata yang lebih tinggi,

\section{Hasil dan pembahasan}

Validasi ahli atau pakar dilakukan oleh 3 validator dengan tujuan untuk melihat kevalidan BIP berjudul "Hewan Berduri dari Pesisir Pulau Denawan" dari kalangan ahli terhadap berbagai aspek yang tertuang di lembar validasi. Hal tersebut sejalan dengan Ibrahim \& Subali (2017) yang menyatakan bahwa validitas merujuk pada kesahihan sebuah buku terhadap berbagai aspek, yang mana proses validasi dilakukan oleh expert judgement dari ahli yang berkompeten pada bidangnya. Hasil validasi ahli terhadap BIP ini dapat dilihat pada tabel 3. 
menyatakan penilaian koherensi bertujuan untuk menciptakan susunan dan struktur sebuah wacana yang bersifat serasi, runtut, dan logis. Bersifat serasi maksudnya sesuai, cocok, dan harmonis yang mana kesesuaiannya terletak pada serasinya hubungan antarproposisi dalam sebuah wacana. Bersifat runtut maksudnya urut, sistematis, dan tidak terputus-putus akan tetapi bertautan satu sama lain. Terakhir bersifat logis yang maksudnya masuk akal, wajar, dan jelas, serta mudah dimengerti.

Sebuah buku yang baik khususnya BIP hendaknya memperhatikan tingkat keterbacaan para pembacanya. Hasil validasi pada aspek ini memperoleh kriteria sangat valid (dapat digunakan tanpa revisi), yang artinya BIP ini telah memenuhi syarat untuk dibaca oleh siswa karena telah sesuai pada tingkatan usia atau pendidikannya. Kesesuaian ini akan memudahkan siswa untuk memahami materimateri pada BIP tentang echinodermata yang berjudul "Hewan Berduri dari Pesisir Pulau Denawan" ini, yang mana hal tersebut dapat meningkatkan minat belajar yang pada akhirnya akan meningkatkan hasil belajar dan kemampuan berpikir kritis siswa tersebut. Hal tersebut sejalan dengan Mulyadi (2015) yang menyatakan bahwa kesesuaian tingkat keterbacaan sebuah buku penting untuk diperhatikan, karena dapat berpengaruh pada minat dan motivasi siswa untuk membaca dan mempelajari materimateri pada buku tersebut.

Kosakata merupakan istilah-istilah yang dapat dipergunakan untuk membentuk sebuah kalimat dalam bahasa Indonesia. Hasil validasi pada tabel 3 menyebutkan bahwa BIP tentang echinodermata yang berjudul "Hewan Berduri dari Pesisir Pulau Denawan” pada aspek kosakata mendapatkan kriteria valid, yang artinya BIP ini pada aspek kosakata sudah dapat digunakan namun ada beberapa hal yang harus direvisi. Kosakata merupakan salah satu hal yang penting dalam penilaian BIP, dimana kosakata yang digunakan harus sesuai dengan kaidah-kaidah bahasa Indonesia yang baik dan benar agar tidak terjadi kesalahpahaman makna. Selain itu BIP ini telah menggunakan kosakata yang sederhana dan menarik, sehingga para pembaca akan mudah dalam memahami isi materi. Hal tersebut sejalan dengan Khairoh, Rusilowati, \& Nurhayati (2014) yang menyatakan sebuah buku dapat dikatakan layak apabila kosakata yang digunakan adalah kosakata sederhana, ringan dan singkat sehingga pembaca dapat lebih mudah memahami isi materi atau cerita.

Kalimat ada yang bersifat aktif dan ada yang bersifat pasif, sebuah wacana hendaknya memenuhi kedua jenis kalimat tersebut walaupun kalimat aktif harus mendominasi agar lebih meningkatkan aktivitas pembaca. Aspek kalimat aktif dan pasif yang menjadi fokus dalam penilain BIP ini ialah kalimat yang digunakan lebih jelas dan meyakinkan. Aspek ini mendapatkan kriteria valid yang artinya sudah dapat digunakan, namun perlu ada beberapa revisi. Hasil ini tidak lepas dari proses pembuatan BIP ini yang telah menyesuaikan keberadaan kalimat aktif dan pasif sehingga dapat menghasilkan wacana yang kalimatnya jelas dan menyakinkan. Hal tersebut sesuai dengan oleh Barnawi \& Arifin (2015) yang menyatakan sebuah karya tulis ilmiah termasuk BIP, harus memasukan kata-kata kerja agar tercipta kalimat aktif yang mengarahkan pembaca untuk melakukan sebuah tindakan.
Sebuah wacana atau kalimat seharusnya mengandung makna yang pasti, sehingga pembaca mendapatkan sebuah informasi yang benar. Aspek melindungi kata-kata yang menjadi fokus dalam penilaian BIP ini ialah tidak menggunakan kata-kata yang bermakna ketidakpastian. Aspek ini memperoleh kriteria sangat valid, yang artinya BIP ini sudah tidak memiliki kata-kata yang maknanya tidak pasti seperti kata "mungkin", hal tersebut dikarenakan dalam pembuatan BIP ini telah menghindari kata-kata yang sifatnya meragukan. Hal tersebut sesuai dengan Suryaman (2012) yang menyatakan bahwa salah satu karakteristik dari sebuah buku pengetahuan seperti BIP ialah memiliki keteraturan dan ketepatmaknaan yang tujuannya agar informasi yang disampaikan penulis akan diterima secara sama oleh penerima, sehingga akan terhindarkan dari adanya salah informasi.

Pada aspek aplikasi dan implikasi yang menjadi fokus dalam penilaian BIP ini ialah penerapan: memasukan isuisu yang layak diberitakan dan potensi aplikasi dunia nyata untuk kepentingan pembaca. Aspek ini mendapatkan kriteria sangat valid yang artinya sudah dapat digunakan tanpa revisi, hasil ini tidak terlepas dari penggunaan bahan atau materi dalam penggembangan BIP ini yang berasal dari materi-materi lokal dari Pulau Sembilan yang sering dijumpai pembaca. Hal ini sejalan dengan Dalman (2014) yang menyatakan bahwa tulisan ilmiah populer hendaknya dutulis berdasarkan data hasil penelitian atau materi yang berasal dari lingkungan sekitar pembaca tinggal, sehingga akan tercipta karya tulis yang bersifat kontekstual yang akan memudahkan pembaca untuk memahami isi dari karya tulis ilmiah populer tersebut karena nanti para pembacalah yang sering berinteraksi dengan lingkungan sekitarnya.

Aspek definisi dan penjelasan yang menjadi fokus dalam penilai BIP ini ialah penjelasan: menjelaskan yang baik seperti mendeskripsikan, memberikan contoh, analogi atau metafora untuk memfasilitasi pemahaman pembaca. Pada aspek ini didapatkan kriteria sangat valid yang artinya penjelasan-penjelasan dalam BIP ini telah sesuai sehingga dapat meningkatkan atau memudahkan para pembaca untuk memahami isi dari BIP ini. Hal ini sejalan dengan Wibowo (2008) yang menjelaskan bahwa pada sebuah karya tulis ilmiah termasuk BIP, bentuk tulisan pada bagian deskripsi mengutamakan kemampuan penulis untuk merinci atau melukiskan peristiwa, kejadian, atau lanskap secara objektif melalui kata-kata, sehingga para pembaca seolah-olah melihat langsung peristiwa atau penjelasan yang tertuang dalam buku tersebut.

Aspek gaya lain perangkat mendapatkan hasil valid yang artinya BIP ini telah memenuhi syarat pada aspek gaya lain perangkat, namun perlu ada revisi kecil. Pada proses pembuatanya, BIP ini telah di sisipkan beberapa cerita, narasi, dan beberapa puisi singkat yang berkaitan dengan materi yang tujuan agar para pembaca mudah memahami isi materi karena dituangkan dalam bentuk cerita. Bentuk tulisan narasi ialah dengan menggarisbawahi aspek penceritaan atas suatu rangkaian peristiwa yang berkaitan secara objektif atau imajinatif dalam kurun waktu tertentu yang harapannya agar pembaca bisa menghayati lika liku cerita yang telah dirangkai (Wibowo, 2008).

Hasil validasi yang dilakukan oleh validator mendapatkan hasil sangat valid pada beberapa aspek dan 
valid pada beberapa aspek yang apabila dikonversikan secara keseluruhan mendapatkan rata-rata kriteria sangat valid. Hasil ini tidak terlepas dari proses pengambangan atau pembuatan BIP tentang echinodermata yang berjudul "Hewan Berduri dari Pesisir Pulau Denawan" itu sendiri, dimana prosesnya dilakukan dengan sangat baik, runtut sesuai dengan prosedur yang telah ditetapkan, dan telah disesuaikan terhadap berbagai aspek-aspek yang ada sehingga produk BIP ini memiliki berbagai keunggulan seperti yang telah dijelaskan di atas. Buku ilmiah populer akan mendapatkan hasil yang sangat baik atau sangat valid apabila proses perancangan dan pengembangan materi pada buku tersebut dilakukan dengan sangat baik (Setiawan, 2017). BIP tentang echinodermata yang berjudul "Hewan Berduri dari Pesisir Pulau Denawan” ini telah memperoleh kriteria sangat valid oleh ketiga validator yang artinya BIP ini sudah dapat digunakan tanpa revisi, akan tetapi peneliti tetap melakukan revisi berdasarkan saran-saran dan komentar yang telah diberikan validator, tujuannya ialah untuk menyempurnakan lagi BIP ini.

BIP tentang echinodermata yang berjudul "Hewan Berduri dari Pesisir Pulau Denawan” yang telah mendapat kriteria sangat valid dari ahli atau pakar akan dilakukan validasi lagi oleh guru mitra. Validasi oleh guru mitra akan dilakukan oleh guru biologi dari SMAN 1 Pulau Sembilan Kotabaru.

Validasi oleh guru mitra juga dilakukan untuk menilai BIP tentang echinodermata yang berjudul "Hewan Berduri dari Pesisir Pulau Denawan” oleh guru sebagai pengguna atau juga bisa disebut dengan uji praktisi. Guru diharapkan memberikan penilaian, komentar, dan saran agar BIP ini menjadi lebih baik sehingga dapat mudah dipahami oleh pemakai. Guru biasanya lebih mengetahui apa-apa saja yang diperlukan untuk memperbaiki sebuah produk pendidikan karena mereka setiap saat berhadapan langsung dengan siswa sebagai pemakai. Hal tersebut sesuai dengan pernyataan Akbar (2013) bahwa validasi pengguna dalam hal ini guru mitra dapat digunakan untuk mengetahui dan merasakan tingkat ketertetapan sebuah buku termasuk BIP yang apabila dilihat dari sisi relevansi, akurasi, keterbacaan, dan kesesuaian dengan pembelajaran yang berpusat pada siswa. Guru mitra dapat melakukan penilaian berdasarkan aspek-aspek yang terdapat dalam instrumen penilaian yang telah tersedia. Hasil validasi guru mitra terhadap BIP ini dapat dilihat pada tabel 4.

Tabel 4. Hasil validasi oleh guru mitra

\begin{tabular}{|c|c|c|}
\hline Aspek & Kriteria penulisan populer & Rata-rata skor \\
\hline Aspek koherensi & $\begin{array}{l}\text { Setiap paragraf memiliki satu ide pokok } \\
\text { Antar kalimat menggunakan penghubung } \\
\text { Ide-ide saling berurutan } \\
\text { Kalimat telah mengarahkan kepada } \\
\text { pemahaman. }\end{array}$ & 4 \\
\hline Aspek keterbacaan & $\begin{array}{l}\text { Teks sesuai dengan tingkat usia/tingkat } \\
\text { pendidikan }\end{array}$ & 4 \\
\hline $\begin{array}{l}\text { Aspek kosa kata: ungkapan, kerja, } \\
\text { pilihan, yang berlebihan. }\end{array}$ & $\begin{array}{l}\text { Penggunaan ungkapan dibatasi } \\
\text { Kosakata yang digunakan sudah } \\
\text { disesuaikan dengan tingkat pembaca }\end{array}$ & 4 \\
\hline Aspek kalimat aktif dan pasif & $\begin{array}{l}\text { Kalimat yang digunakan lebih jelas dan } \\
\text { meyakinkan }\end{array}$ & 4 \\
\hline $\begin{array}{c}\text { Aspek melindungi nilai: kata-kata yang } \\
\text { bermakna ketidakpastian }\end{array}$ & $\begin{array}{l}\text { Tidak menggunakan kata-kata yang } \\
\text { bermakna ketidakpastian }\end{array}$ & 4 \\
\hline Aspek aplikasi, implikasi & $\begin{array}{l}\text { Penerapan: memasukkan isu-isu yang layak } \\
\text { diberitakan dan potensi aplikasi dunia } \\
\text { nyata untuk kepentingan pembaca }\end{array}$ & 3 \\
\hline Aspek definisi dan penjelasan & $\begin{array}{l}\text { Penjelasan: menjelaskan yang baik seperti } \\
\text { mendeskripsikan memberikan contoh, } \\
\text { analogi atau metafora untuk memfasilitasi } \\
\text { pemahaman pembaca }\end{array}$ & 3 \\
\hline $\begin{array}{l}\text { Aspek gaya lain perangkat: narasi, } \\
\text { humor, analogi. }\end{array}$ & $\begin{array}{l}\text { Penggunaan analogi untuk menjelaskan ide } \\
\text { yang kompleks. } \\
\text { Penggunaan narasi untuk menjelaskan } \\
\text { seperti dalam cerita fiksi } \\
\text { Penggunaan humor untuk kreativitas }\end{array}$ & 3 \\
\hline $\begin{array}{c}\text { Total skor } \\
\text { Persentase }(\%) \\
\text { Kriteria keseluruhan }\end{array}$ & & $\begin{array}{c}29 \\
90,1 \\
\text { Sangat valid }\end{array}$ \\
\hline
\end{tabular}

Berdasarkan hasil validasi (tabel 4) oleh guru mitra terhadap BIP tentang echinodermata yang berjudul "Hewan Berduri dari Pesisir Pulau Denawan" diperoleh nilai persentase sebesar 90,1\% yang termasuk kedalam kriteria sangat valid atau dapat digunakan tanpa melakukan revisi. Hal tersebut sejalan dengan penelitian Sumiarta (2016) yang mendapatkan hasil $88,32 \%$ untuk validasi guru mitra yang mana hasil tersebut termasuk kedalam kriteria sangat valid.

BIP berjudul "Hewan Berduri dari Pesisir Pulau Denawan" mendapatkan kriteria sangat valid dari guru mitra, hal tersebut dikerenakan dalam pembuatannya BIP ini telah memenuhi berbagai aspek sebagai syarat yang diperlukan dalam pengembangan sebuah buku ilmiah populer. Hal tersebut senada dengan Akbar (2013) yang 
menyatakan sebuah buku yang baik harus memenuhi beberapa aspek tertentu sebagai syarat buku yang baik termasuk buku ilmiah populer seperti: akurat yang artinya tidak salah dalam menjabarkan hasil penelitian dan pengutipan teori-teori, relevan yang artinya memiliki kesesuaian antara kompetensi dengan cakupan isi dan kedalaman pembahasan, komunikatif yang artinya bahasa pada isi buku tidak semuanya formal melainkan setengah lisan atau seperti bercerita, lengkap yang artinya materi yang tertuang dalam sebuah buku tidak hanya membahas 1 atau 2 pembahasan akan tetapi membahas materi secara menyeluruh, dan sistematis yang artinya materi yang disajikan mengikuti alur pikir sederhana ke kompleks.

Guru mitra juga memberi komentar terhadap BIP tentang echinodermata yang berjudul "Hewan Berduri dari Pesisir Pulau Denawan” yang tujuannya ialah agar BIP ini lebih mendekati sempurna. Hal ini menjelaskan bahwa dalam proses evaluasi terhadap sebuah bahan ajar termasuk BIP dapat dilakukan kepada guru mitra yang tujuannya ialah untuk mengetahui apakah bahan ajar tersebut telah sesuai dengan kebutuhan dan masih memiliki kekurangan, sehingga dapat dilakukan perbaikan.

Setelah BIP tentang echinodermata yang berjudul "Hewan Berduri dari Pesisir Pulau Denawan" dinyatakan sangat valid dari ahli atau pakar dan guru mitra, maka langkah selanjutnya ialah dilakukan uji perorangan. $U_{j i}$ perorangan yang juga bisa disebut dengan uji keterbacaan akan dilakukan oleh siswa-siswi dari SMAN 1 Pulau Sembilan Kotabaru.

Uji perorangan atau juga bisa disebut dengan uji keterbacaan dilakukan oleh 3 siswa-siswi SMAN 1 Pulau Sembilan kelas XI IPA yang telah tuntas dalam pembelajaran echinodermata (invertebrata), penunjukan siswa-siswi ini dilakukan langsung oleh pihak sekolah. Uji perorangan bertujuan untuk melakukan penilaian oleh siswa yang menjadi pemakai BIP tentang echinodermata yang berjudul "Hewan Berduri dari Pesisir Pulau Denawan”. Penilaianya dilakukan terhadap 2 aspek yaitu aspek tampilan dan aspek penyajian. Hal tersebut sejalan dengan Akbar (2013) yang menyatakan bahwa uji perorangan atau validasi audience (siswa/pembaca) dapat digunakan dalam penilaian sebuah buku, termasuk BIP ini. Hasil uji perorangan dapat dilihat pada tebel 5 dibawah:

Tabel 5. Hasil uji perorangan

\begin{tabular}{|c|c|c|c|c|c|}
\hline \multirow{2}{*}{$\begin{array}{c}\text { Aspek } \\
\text { Penilaian }\end{array}$} & \multicolumn{3}{|c|}{ Nilai (\%) } & \multirow{2}{*}{$\begin{array}{c}\text { Rata- } \\
\text { rata } \\
(\%)\end{array}$} & \multirow{2}{*}{ Kriteria } \\
\hline & MI & MA & $\mathrm{HM}$ & & \\
\hline Aspek & & & & & \\
\hline $\begin{array}{l}\text { Tampilan } \\
\text { Buku Ilmiah } \\
\text { Populer } \\
\text { Aspek }\end{array}$ & 85 & 100 & 90 & 91.7 & $\begin{array}{l}\text { Sangat } \\
\text { baik }\end{array}$ \\
\hline $\begin{array}{l}\text { Penyajian } \\
\text { Materi Buku } \\
\text { Ilmiah } \\
\text { Populer }\end{array}$ & 87.5 & 93.75 & 84.375 & 88.5 & $\begin{array}{l}\text { Sangat } \\
\text { baik }\end{array}$ \\
\hline Rata-Rata & 86.2 & 96.9 & 87.2 & 90.1 & $\begin{array}{l}\text { Sangat } \\
\text { baik }\end{array}$ \\
\hline
\end{tabular}

91,7\% untuk aspek tampilan BIP dan 88,5\% untuk aspek penyajian BIP yang mana kedua aspek tersebut tergolong pada kriteria sangat baik. Sedangkan untuk rata-rata persentase dari kedua aspek tersebut ialah sebesar 90,1\% yang juga termasuk pada kriteria sangat baik. Hasil tersebut sejalan dengan Setiawan (2017) yang mengembangkan buku ilmiah populer yang berjudul "Tumbuhan Survival di Kawasan Taman Nasional Bromo Tengger Semeru” yang hasilnya ialah buku ilmiah populer tersebut mendapatkan kriteria sangat baik pada uji keterbacaan atau uji perorangan.

Sebuah BIP seharusnya memperhatikan aspek tampilan dalam pengembangannya. Tampilannya hendaknya di buat semenarik mungkin untuk memudahkan pembaca untuk memahami materi. Pada aspek tampilan didapat hasil $91,7 \%$ yang artinya BIP ini sangat baik digunakan tanpa adanya revisi. Hasil ini tidak terlepas dari proses pengembangan BIP tentang echinodermata yang berjudul "Hewan Berduri dari Pesisir Pulau Denawan" telah memperhatikan aspek tampilan dengan menampilkan lebih banyak gambar yang dapat menarik pembaca agar lebih termotivasi mempelajari BIP ini. Selain itu tampilan tulisan telah dibuat semenarik mungkin, sehingga pembaca tidak akan bosan membaca BIP ini. pembaca akan lebih mudah mempelajari sebuah buku dengan adanya gambar yang menarik dan bersifat menghibur daripada membaca buku yang bersifat verbal, hal tersebut dikarenakan tampilan warna atau gambar dapat memperlancar pemahaman dan memperkuat ingatan siswa tentang suatu materi (Khairoh et al., 2014).

Penilain BIP tentang echinodermata yang berjudul "Hewan Berduri dari Pesisir Pulau Denawan" pada uji perorangan juga memperhatikan aspek penyajian. Hasil uji perorangan pada tabel 5 diketahui bahwa BIP ini pada aspek penyajian mendapat kriteria sangat baik, hasil tersebut tidak terlepas dari proses pengembangan BIP ini yang telah memperhatikan dengan serius aspek penyajian. Penyajian materi atau konsep pada BIP ini dilakukan dengan runtut dan sistematis sehingga akan meningkatkan motivasi siswa untuk belajar. Pernyataan diatas sejalan dengan Depdiknas, (2008) yang menyebutkan bahwa penyajian materi pada sebuah buku harus dilakukan bersistem, lugas, dan mudah dipahami sehingga dapat menumbuhkan motivasi pembaca untuk mengetahui lebih jauh materi yang disajikan.

Berdasarkan hasil yang telah dijabarkan diatas dari uji perorangan dapat diketahui bahwa BIP yang dikembangkan memperoleh kriteria sangat baik yang artinya BIP tersebut mudah untuk dipahami dan mudah diaplikasikan materinya dalam kehidupan sehari-hari oleh siswa sebagai pembaca. Uji perorangan ini sangat penting untuk dilakukan agar BIP yang telah dikembangkan ini dapat sesuai dengan kondisi siswa atau pembaca yang akan menggunakannya dalam pembelajaran dilapangan secara riil. Penjelasan tersebut sesuai dengan Achyani, Rustaman, Redjeki, \& Choesin (2010) yang menjelaskan bahwa proses pendidikan di sekolah seharusnya mengakomodasi kenyataan di lingkungan sekitar siswa, diharapkan siswa dapat mencari jawaban terhadap kenyataan tersebut. Sehingga pembelajaran di sekolah bukan hanya untuk menghafal 
teori-teori saja, akan tetapi untuk berteori sesuai perubahan pada kenyataan yang ditemukan siswa.

Pada uji perorangan juga diperoleh beberapa komentar dan saran-saran dari siswa-siswi SMAN 1 Pulau Sembilan. Sehingga peneliti merasa perlu melakukan revisi berdasarkan saran dan komentar dari siswa-siswi terhadap BIP berjudul "Hewan Berduri dari Pesisir Pulau Denawan" sebagai pemakai untuk lebih menyempurnakan produk ini.

\section{Simpulan}

Buku ilmiah populer tentang echinodermata yang berjudul "Hewan Berduri dari Pesisir Pulau Denawan" yang telah dikembangkan memiliki tingkat validitas yang sangat tinggi berdasarkan hasil validasi ahli, validasi guru mitra, dan uji perorangan. Hal tersebut dikarenakan BIP yang telah dikembangkan bersifat kontektual, memiliki bahasa yang mudah dipahami, memiliki tampilan yang menarik, sesuai dengan pembelajaran saintifik, dan dapat mengembangkan kemampuan berpikir kritis.

\section{Ucapan terima kasih}

Dengan selesainya artikel ini, saya mengucapkan terima kasih kepada kedua orang tua yang selalu mendukung saya dalam melakukan segala hal yang baik. Ucapan terima kasih juga saya ucapkan kepada Bapak Prof. Dr. Ir. H. Yudi Firmanul Arifin, M. Sc dan Prof. Dr. Ir. Danang Biyatmoko, M. Si karena telah membantu memberikan ide gagasan dan saran-saran selama penelitian ini berlangsung. Selain itu saya sebagai penulis juga mengucapkan terima kasih kepada Dr. H. Aminuddin PP, M.Pd., Dr. Dharmono, M.Si., Dr. H. Muhammad Zaini, M.Pd. dan Nurhikmah, S. Pd telah memberikan kritik dan saran dalam proses penyusunan buku ilmiah populer tentang echinodermata.

\section{Referensi}

Achyani, A., Rustaman, N. Y., Redjeki, S., \& Choesin, D. N. (2010). Model penulisan buku ajar biologi SMA berwawasan ekologi dan lokal untuk meningkatkan kepedulian siswa terhadap lingkungan. BIOEDUKASI (Jurnal Pendidikan Biologi), 1(1). https://doi.org/10.24127/bioedukasi.vli1.180

Akbar, S. (2013). Instrumen Perangkat Pembelajaran. Bandung: Remaja Rosdakarya.

Aunurrahman. (2014). Belajar dan Pembelajaran. Bandung: CV Alfabeta.

Barnawi, \& Arifin, M. (2015). Teknik Penulisan Karya Ilmiah. Yogyakarta: Ar-Ruzz Media.

Dalman. (2014). Menulis Karya Ilmiah. Jakarta: PT Raja Grafindo Persada.

Dekdiknas. (2008). Pedoman Penulisan Buku Nonteks (Buku Pengayaan, Referensi, dan Panduan Pendidik). (Suherli, Ed.). Jakarta: Depdiknas.

Dharmono, Syahdi, N., \& Muchyar. (2017). The development of handout on palm tree population structure at Rampah Manjangan Waterfall. In Proceedings of the 5th SEA-DR (South East
Asia Development Research) International Conference 2017 (SEADRIC 2017). Banjarmasin: Universitas Lambung Mangkurat.

Ibrahim, M., \& Subali, B. (2017). Pengembangan bahan ajar \& pengembangan instrument pengukuran pembelajaran biologi. Banjarmasin: ULM Press.

Khairoh, L., Rusilowati, A., \& Nurhayati, S. (2014). Pengembangan buku cerita IPA terpadu bermuatan pendidikan karakter peduli lingkungan pada tema pencemaran lingkungan. Unnes Science Education Journal, 3(2).

Lestari, I. (2012). Pengembangan bahan ajar berbasis kompetensi. Padang: Akademia.

Mahmud, H. (2013). Guru di tengah perubahan kurikulum. Al-Khwarizmi: Jurnal Pendidikan Matematika dan Ilmu Pengetahuan Alam, 1(2), 111-124.

Millah, E. S., Budipramana, L. S., \& Isnawati. (2012). Pengembangan buku ajar materi bioteknologi di kelas XII SMA IPIEMS Surabaya berorientasi sains, teknologi, lingkungan, dan Masyarakat (SETS). BioEdu, 1(1), 19-24.

Mulyadi. (2015). Tingkat keterbacaan reading materials dalam mata kuliah telaah teks bahasa inggris StAIN Pamekasan. NUANSA: Jurnal Penelitian Ilmu Sosial dan Keagamaan Islam, 12(1), 121141.

Nontji, A. (2007). Laut Nusantara. Jakarta: Djambatan.

Pammai, K. (2014). Studi Keanekaragaman Anggrek di Kabupaten Merauke untuk Pengembangan Buku Ilmiah Populer sebagai Upaya Pelestarian Sumber Daya Lokal bagi Masyarakat di Kabupaten Merauke. Universitas Negeri Malang, Malang.

Pasemawati, A. Y., Fadiawati, N., \& Tania, L. (2013). Pengembangan media animasi berbasis representasi kimia pada materi reaksi oksidasi reduksi. Jurnal Pendidikan dan Pembelajaran Kimia, 2(3).

Plomp, T., \& Nieveen, N. (2007). An introduction to educational design research. In Proceedings of the seminar conducted at the East China Normal University, Shanghai (PR China) (hal. 23-26).

Setiawan, M. E. (2017). Pengembangan Buku Ilmiah Populer untuk Masyarakat Pencinta Alam Melalui Eksplorasi Tumbuhan Survival di Kawasan Taman Nasional Bromo Tengger Semeru. Universitas Negeri Malang.

Setyosari, P. (2013). Metode Penelitian Pendidikan \& Pengembangan. Jakarta: Kencana.

Suja, I. wayan. (2010). Pengembangan buku ajar sains SMP mengintegrasikan content dan context pedagogi budaya Bali. Jurnal Pendidikan dan Pengajaran, 43(1), 79-88.

Sumiarta, I. N. (2016). Pengembangan Bahan Ajar Berbasis Hasil Penelitian Jenis Plankton Kawasan Pantai Angsana Kecamatan Angsana Sebagai Materi 
Pengayaan Konsep Protista Di SMA. Universitas Lambung Mangkurat, Banjarmasin.

Suryaman, M. (2012). Penggunaan Bahasa Di Dalam Penulisan Buku Nonteks Pelajaran. Jakarta: Pusat Kurikulum Dan Perbukuan Balitbang Kementerian Pendidikan Dan Kebudayaan.

Tessmer, M. (1993). Planning and conducting formative evaluations. London: Routledge.

Trianto. (2008). Mendesain pembelajaran kontekstual di kelas. Surabaya: Cerdas Pustaka.
Wibowo, W. (2008). Berani Menulis Artikel. Jakarta: Gramedia Pustaka Utama.

Widiatmoko, W. (2015). Analisis Kohesi dan Koherensi Wacana Berita Rubrik Nasional di Majalah Online Detik. Jurnal Sastra Indonesia, 4(1).

Zakyah. (2016, Januari 20). Pengaruh Struktur Pasir Terhadap Tingkat Keberhasilan Penetasan Telur Penyu Hijau Di Sukamade Taman Nasional Meru Betiri Serta Pemanfaatanya Sebagai Buku Ilmiah Populer. Universitas Negeri Jember, Jember. 